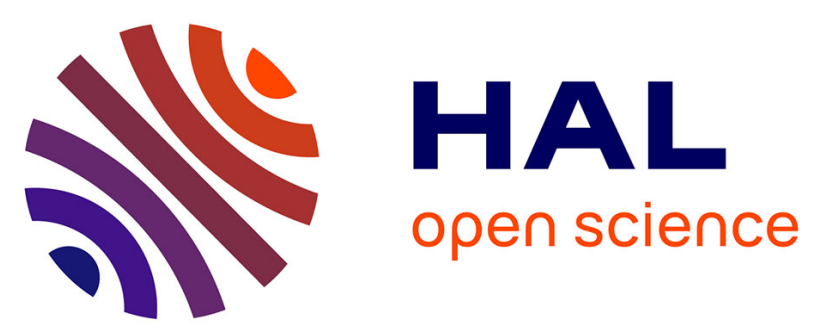

\title{
Local Open Government: Empirical Evidence from Austrian Municipalities
}

Lisa Schmidthuber, Bernhard Krabina, Dennis Hilgers

\section{To cite this version:}

Lisa Schmidthuber, Bernhard Krabina, Dennis Hilgers. Local Open Government: Empirical Evidence from Austrian Municipalities. 17th International Conference on Electronic Government (EGOV), Sep 2018, Krems, Austria. pp.110-119, 10.1007/978-3-319-98690-6_10 . hal-01961512

\section{HAL Id: hal-01961512 \\ https://hal.inria.fr/hal-01961512}

Submitted on 20 Dec 2018

HAL is a multi-disciplinary open access archive for the deposit and dissemination of scientific research documents, whether they are published or not. The documents may come from teaching and research institutions in France or abroad, or from public or private research centers.
L'archive ouverte pluridisciplinaire HAL, est destinée au dépôt et à la diffusion de documents scientifiques de niveau recherche, publiés ou non, émanant des établissements d'enseignement et de recherche français ou étrangers, des laboratoires publics ou privés. 


\title{
Local Open Government: Empirical Evidence from Austrian Municipalities
}

\author{
Lisa Schmidthuber ${ }^{10000-0002-0349-9965]}$, Bernhard Krabina ${ }^{20000-0002-6871-3037]}$ and Dennis \\ Hilgers ${ }^{1[0000-0003-2660-7057]}$ \\ ${ }^{1}$ Johannes Kepler University, Altenbergerstraße 69, 4040 Linz, Austria \\ ${ }^{2} \mathrm{KDZ}$ - Centre for Public Administration, Guglgasse 13, 1110 Vienna, Austria \\ lisa.schmidthuber@jku.at
}

\begin{abstract}
Local governments have increasingly been applying an open and collaborative approach towards public management during the last years. Accordingly, they aim at increasing accessibility by releasing public data and providing participative decision-making arenas. 'Open government' has also been implemented in Austrian municipalities. This paper takes stock of the current status of open government implementation in Austria by analyzing survey data from city managers. Findings indicate that Austrian municipalities choose releasing public data over involving citizens in decision-making. Although public managers seem to value the principles of an open government, a successful implementation of open government is hampered by resource constraints.
\end{abstract}

Keywords: Open Government, Local Government, Public Manager.

\section{Introduction}

Decreasing levels of public trust, low citizen satisfaction with the politicaladministrative system, and a changing political landscape are challenging government institutions, public sector organizations, and political parties alike. These acceptance and legitimacy problems assert pressure on the political-administrative system to change and innovate the present process of public service delivery and policy-making. In fact, various public institutions respond to these challenges by providing citizens free access to public data and possibilities of participative decision-making.

Various scholars (e.g. [13], [16], [17], [20]) gave promising results of 'open innovation' as used in the public sector. They suggested that online platforms, social media, and mobile applications are leveraged to enhance the dialogue between government and citizens. Knowledge flows in digital platforms further hold great potential for value-creation both for society and participants [16]. The implementation of open government was, however, only investigated by pointing to specific open government projects or best practices so far (e.g. [20]). Unfortunately, research has not yet examined to what extent open government is implemented across local governments, independent from size. Consequently, one cannot formulate more general statements on 
factors facilitating or hampering open government implementation. Moreover, there is little research on city managers' perceptions on open government [4, 25].

This paper thus contributes to the research on open government by taking stock of open government implementation in Austrian municipalities. It intends to evaluate the current status of adoption, analyze municipalities' capability for implementation, and shed light on city managers' attitudes towards governmental openness.

The remainder of this paper is structured as follows: In section 2, we introduce the concept of open government. Section 3 describes the data and method used in this study. In section 4, empirical findings are presented. Section 5 encompasses a discussion of our findings, gives implications of this research, and points to limitations and avenues for further research.

\section{Open Government}

Open government as a 'multilateral, political, and social process' [23, p. 2] is widely understood as a concept that transforms governments and is meant to connect government with citizens who are supposed to introduce innovative solutions based on their local knowledge and experience [18]. Meijer, Curtin, and Hillebrandt [15] associate open government with citizens' vision of 'what is going on inside government' and their voice in interactive terms, the term denotes governmental activities for the benefit of transparency, participative decision-making, and collaborative activities between policymakers and citizens (e.g. [3], [12]). An 'open government' thus encompasses an increased level of openness in terms of information and decisionmaking and can be seen as the comprehensive redesign of politics and administrative activities according to the principles of modern public management and public governance (see Fig. 1).

The public sector utilizes various ways to promote transparency of government action, accessibility of government services and information as well as the integration of externals by leveraging modern information and communication technology [11, 13, $15,16,17,23]$. Significantly, opening government to the public sphere requires a border crossing for the respective public organizations, meaning that new forms of cooperation are implemented and external sources of knowledge are consulted for specific issues [8]. More typical forms of participation such as elections and referendums fail to adequately transfer either knowledge or needs from society to government. Openness and free access to information, however, facilitate the interaction between government and civil society and promote a participatory government [14]. Citizens and experts provide know-how that governments then apply in problem solving and draw on when developing innovative strategies and policies $[13,21]$. 


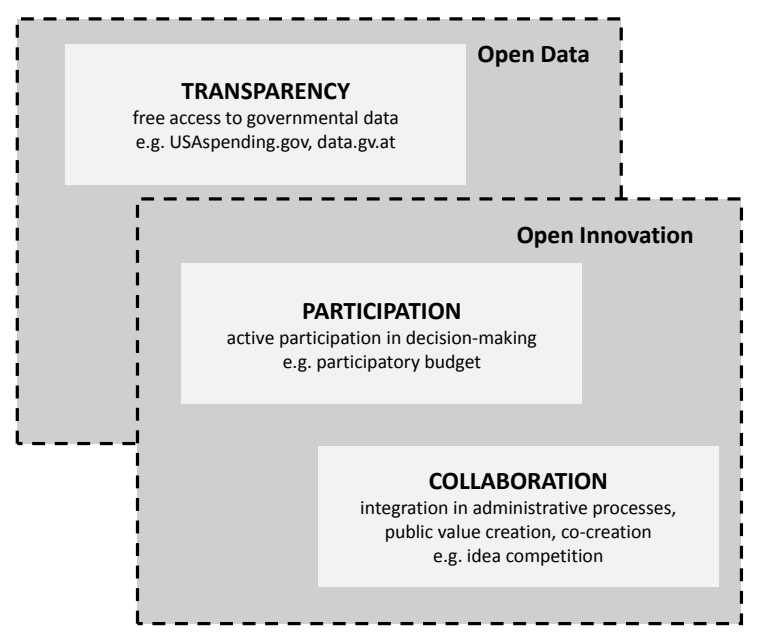

Fig. 1. Open Government, [20]

With this in mind, integrating citizens into organizational processes and governmental decision may result in various benefits. First, applying open government is assumed to enhance government-citizen relation. Opening up government improves perceptions of fairness among the public, strengthens democracy insofar as personal responsibility and public spirit can be enhanced, democratic accountability, and trust in government $[7,10]$. Second, openness in the public sector may lead to advantages for public administration and its organizational processes, as the new approach benefits organizational and policy performance [6, 18], efficiency and effectiveness of public services and governmental procedures [16, 18, 23] as well as quality enhancements $[9,16,19]$. In summary, open government activities are assumed to enhance public value.

\section{Data and Methods}

To explore the current status of open government implementation in Austria, we collected survey data in Austrian municipalities. Austria is a federal state consisting of nine regions and 2,100 local governments ${ }^{1}$. Municipalities are characterized by local autonomy, which means that they are governed by a local council with the mayor as its head. The mayor is elected by the local council or local inhabitants for five or six years. Whereas the mayor represents the political decision-maker of local government, the city manager or chief executive officer is subject to directives from the mayor and responsible for operational matters. In November 2016, city managers of all Austrian municipalities received an online questionnaire with a number of closed questions. 235 city managers completed the questionnaire.

\footnotetext{
${ }^{1}$ At the time of the analysis, Austria had 2,100 municipalities.
} 


\section{$4 \quad$ Findings}

\subsection{Sample Description}

Table 1 summarizes key characteristics of the sample population, and contrasts it from the Austrian population. Expect for Vienna, individuals from all federal states respond to our survey invitation. The greatest share of respondents are from Upper Austria as the second largest federal state. Furthermore, the sample varies among municipal size. About one third of all respondents work in small municipalities, one third in large municipalities, and one third is in between. In addition, the level of debt of sample municipalities is comparable to the actual Austrian distribution. Consequently, we conclude that the survey sample resembles the Austrian structure of municipalities in terms of federal state, municipal size, and level of debt.

Table 1. Sample Description

\begin{tabular}{|c|c|c|}
\hline & $\begin{array}{c}\text { Sample } \\
\text { distribution }\end{array}$ & $\begin{array}{c}\text { Austrian } \\
\text { distribution }\end{array}$ \\
\hline \multicolumn{3}{|l|}{ Federal state } \\
\hline Burgenland & $12(5.11 \%)$ & $171(8.14 \%)$ \\
\hline Carinthia & $20(8.51 \%)$ & $132(6.29 \%)$ \\
\hline Lower Austria & $58(24.68 \%)$ & $573(27.29 \%)$ \\
\hline Upper Austria & $80(34.04 \%)$ & $442(21.05 \%)$ \\
\hline Salzburg & $15(6.38 \%)$ & $119(5.67 \%)$ \\
\hline Styria & $20(8.51 \%)$ & $287(13.67 \%)$ \\
\hline Tyrol & $21(8.94 \%)$ & $279(13.29 \%)$ \\
\hline Vorarlberg & $9(3.83 \%)$ & $96(4.57 \%)$ \\
\hline Vienna & - & 1 \\
\hline \multicolumn{3}{|l|}{ Municipal size } \\
\hline small & $80(34.04 \%)$ & $830(39.52 \%)$ \\
\hline intermediate & $91(38.72 \%)$ & $721(34.33 \%)$ \\
\hline large & $64(27.23 \%)$ & $549(26.14 \%)$ \\
\hline \multicolumn{3}{|c|}{ Level of debt per capita } \\
\hline low & $144(61.28 \%)$ & $1364(64.95 \%)$ \\
\hline intermediate & $59(25.11 \%)$ & $409(19.70 \%)$ \\
\hline high & $32(13.62 \%)$ & $303(14.60 \%)$ \\
\hline Observations & 235 & 2,100 \\
\hline
\end{tabular}

Source: Statistics Austria

\subsection{Open Government Implementation in Austrian Municipalities}

In order to evaluate the status of open government implementation in Austria, we developed a list with practices associated with open government. Figure 2 illustrates the survey results and indicates if the responding municipality has already implemented a practice, is intended to implement it, or is not willing to take action. 
Release public data on open data portals (e.g. data.gv.at, offenerhaushalt.at, national/federal state/EU-portals)

Online forms for citizens' requests

Gather ideas and needs from citizens (e.g. online surveys)

Exchange with companies (e.g. projects, meetings, invitations, committee work, information events)

Provide municipal information via mobile application

Release of municipal budget information on a website/portal

Communicate with citizens via social media (e.g. Facebook, Twitter)

Consult citizens concerning ideas on urban and building planning (e.g. idea platform)

Provide information (e.g. official announcements) via social media (e.g. Facebook, Twitter)

Offer an online platform for interaction with and among citizens

Establish a person in charge for social media activities (e.g. social media agent)

Exchange with universities, research facilities, universities of applied sciences (e.g. third-party funds projects, reports, expert meetings)

Obtain proposals for solutions from citizens online (e.g. problems concerning infrastructure)

Public consultation concerning collaborative agend planning (e.g. digital agenda planning)

Post meetings (e.g. local council meetings) or events (e.g municipal events) via video livestream

Consultation of citizens concerning budget plans (e.g. online participatory budget)
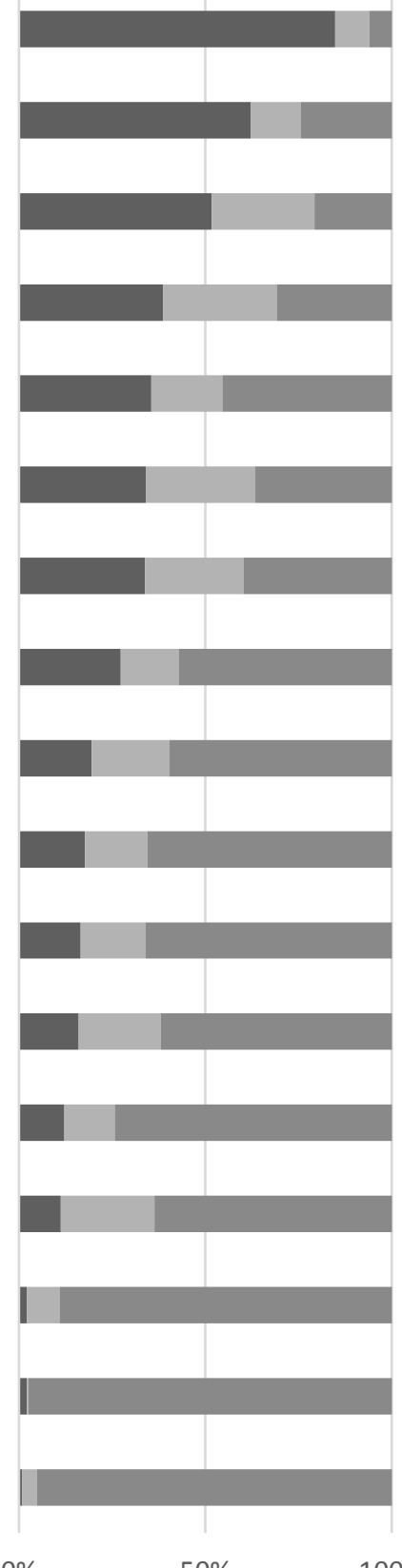

- Implemented Intention to Implement $\quad$ No Intention to Implement

Fig. 2. Open Government Practices in Austria. 
First, findings show that the status of implementation greatly varies across municipalities. For example, 63 municipalities use social media channels to communicate with citizens, whereas 132 municipalities have no intention to set up a social media account. Second, the results indicate a great difference in the implementation status in terms of type of practice. On the one hand, the majority of city managers report to exchange with other municipalities, release public data on open data portal, and provide online forms for citizens' requests. On the other hand, however, only very few municipalities consult citizens in terms of budgeting or agenda planning and rather have no intention to do so in the future.

\subsection{Capability to Implement Open Government}

Based on the main ideas of the resource-based view, more resources are associated with a higher level of organizational performance [22]. Organizational resources are also shown to influence public innovation [2]. Open government implementation thus requires organization's capability to provide relevant practices. Accordingly, municipalities must have resources to ensure transparency, provide citizen participation, and foster collaboration. We thus ask city managers if current resources are adequate for implementing open government practices. As illustrated in Figure 3, municipalities seem to suffer from resource scarcity. Whereas technical equipment for disclosing data and integrating citizens as well as security arrangements are available to a certain level, financial and human resources do not hold for adopting open government.

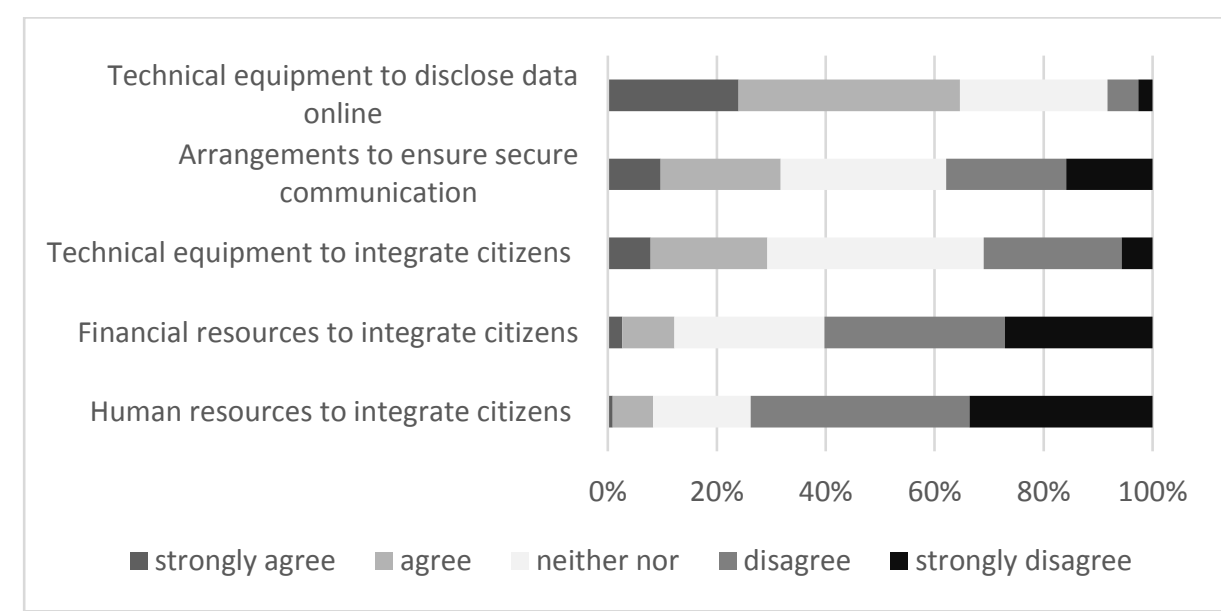

Fig. 3. Resources.

Note: $\mathrm{N}=227-229$

Next to material resources, open government implementation requires task knowledge. Accordingly, public employees have to know how to implement open government. In Figure 4, we give an overview on respondents' statements on the level of task knowledge. The results show that the majority of municipalities have 
knowledge in releasing public data. Furthermore, they seem to know how to transfer citizens' input into improvements of organizational activities. In addition, about 60 percent of municipalities are able to manage citizens' contributions.

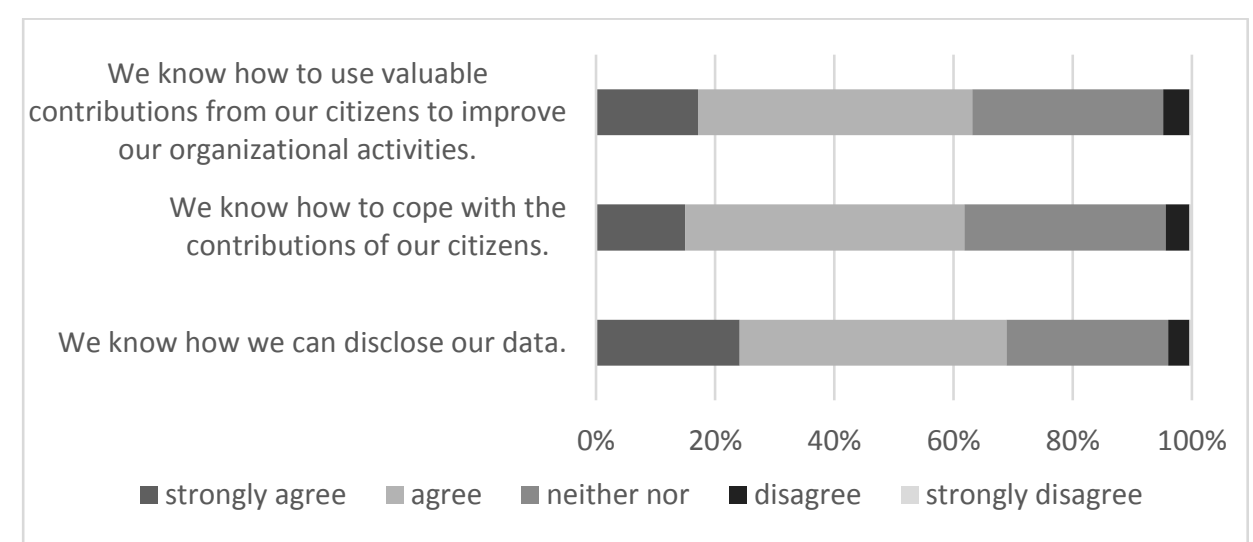

Fig. 4. Knowledge.

$\mathrm{N}=228-229$

\subsection{Attitudes towards Open Government}

Next to organizational factors crucial for open government adoption, we concentrate on decision-makers' attitudes towards innovative practices. Shedding light on the perceptions of municipal city managers is important, as they are main decisionmakers in implementing public change and innovation [5, 24], and thus influence strategic decisions [1]. Accordingly, we first focuses on city managers' attitudes towards government. Results in Figure 5 show that about 30 percent of city managers seem to value the ideas from citizens, even more than internal ones. However, only few managers agree that citizen involvement can lead to an improvement of organizational action. 
Ideas from our citizens to improve organizational processes are more

valuable than internal solutions.

The stronger focus of the local government on our citizens is an

improvement on our previous actions.

Our organizational action will lose quality if we open our processes to our citizens.

We can better understand the needs of our citizens if we integrate them into our organizational and decision-making processes.

I think that our local government benefits from a greater involvement of our citizens.

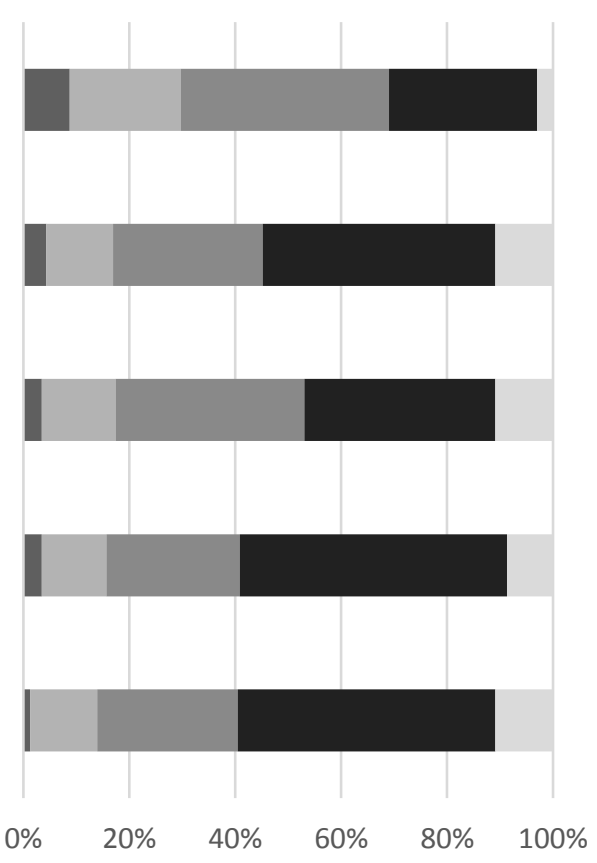

$\square$ strongly agree $\quad$ agree $\quad$ neither nor $\quad$ disagree $\quad$ strongly disagree

Fig. 5: Attitudes towards Open Government

$\mathrm{N}=229-230$

Second, we question the perceived value of open government. As summarized in Figure 6, city managers seem to value open government practices in terms of citizen integration and transparency. In contrast, they are less convinced of open government as a tool to compensate losses in public trust and citizen confidence. 


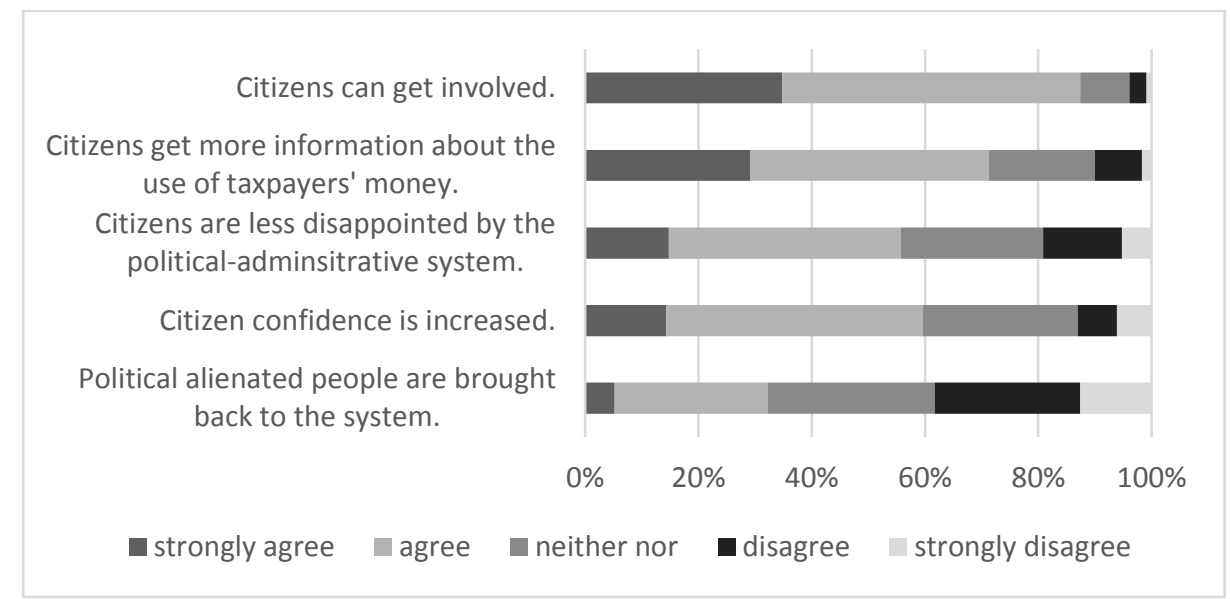

Fig. 6. Outcomes of Open Government

$\mathrm{N}=230$.

\section{$5 \quad$ Discussion and Conclusion}

The findings of this study show a diverse picture of open government in Austrian municipalities. First, while municipalities value the exchange of experiences with each other, they seem to be quite reluctant to adopt open government ideas in terms of participation and collaboration. Second, city mangers seem to rate the outcomes of open government rather positively. However, they refer to a lack of available organizational and financial resources as a barrier to implement open government in their organizations successfully. One could thus explain a low level of open government adoption with a lack of resources. While scarce resources are certainly a problem in some municipalities, however, the question of re-allocation resources from other tasks to the tasks at hand regarding the open government agenda might arise. Here, the question of attitude towards open government speaks a clear language: when almost 60 percent of public managers do not think that their local governments can benefit from a greater involvement of their citizens, why should they shift resources to topics they are not ordered to do so by the politicians in charge or required by law.

Concluding, this study confirms two observations in Austria. First, the open government discussion in Austria has been focusing mainly on open government data (OGD), rather than participative decision-making and collaboration. Whereas municipalities are ready to disclosure data, they seem to be not willing to involve external actors in organizational processes. For example, whereas many German cities have already adopted various rounds of participatory budgeting, Austrian municipalities are not taking up on this practice. Second, survey findings indicate that the open government agenda is valued in general. Few Austrian cities have already initiated large open government projects (see [20]). However, the majority of Austrian municipalities suffer from resource constrains for realizing the open government agenda. Conse- 
quently, open government has to be move to political representatives who has to actively push and promote the topic.

Further research has thus to shed light on the role of politicians and investigate their perception toward open government. A further avenue of research relates to the extent to which municipalities have adopted open government. Whereas this study makes a first step towards illustrating what open government means in practice, further research is recommended to elaborate a scale and give a more holistic picture of the quantity and quality of open government practices. Furthermore, we know little about what public datasets are released, how often they are downloaded by citizens, and if citizen expectations are fulfilled.

\section{References}

1. Damanpour, F., Schneider, M.: Phases of the adoption of innovation in organizations: Effects of environment, organization and top managers. British Journal of Management, 17(3), 215-236 (2006).

2. De Vries, H., Bekkers, V., Tummers, L.: Innovation in the public sector: A systematic review and future research agenda. Public Administration, 94(1): 146-166 (2016).

3. Evans, A. M., Campos, A.: Open government initiatives: Challenges of citizen participation. Journal of Policy Analysis and Management, 32(1), 172-185 (2013).

4. Ganapati, S., \& Reddick, C. G.: The use of ICT for open government in US municipalities: Perceptions of chief administrative officers. Public Performance \& Management Review, 37(3), 365-387 (2014).

5. Hansen, M.B.: Antecedents of organizational innovation: The diffusion of new public management into Danish local government. Public Administration, 89(2), 285-306 (2011).

6. Harrison, T. M., Guerrero, S., Burke, G. B., Cook, M., Cresswell, A., Helbig, N., Hrdinova, J., Pardo, T.: Open government and e-government: Democratic challenges from a public value perspective. Information Polity 17 (2): 83-97 (2012).

7. Herian, M.1 N., Hamm, J. A., Tomkins, A. J., Pytlik Zillig, L. M.: Public participation, procedur-al fairness, and evaluations of local governance: The moderating role of uncertainty. Journal of Public Administration Research and Theory 22 (4): 815-840 (2012).

8. Hilgers, D.: Open Government. Zeitschrift für Betriebswirtschaft, 82(6), 631-660 (2012).

9. Hilgers, D., Ihl, C: Citizensourcing: Applying the concept of open innovation to the public sector. The International Journal of Public Participation 4 (1): 67-88 (2010).

10. Janssen, M., Charalabidis, Y., Zuiderwijk, A: Benefits, adoption barriers and myths of open data and open government. Information Systems Management 29 (4): 258-68 (2012).

11. Krabina, B., Lutz, B. (2016). Open Government Implementation Model. Online in: http://www.kdz.eu/en/open-government-implementation-model, last accessed 2018/03/15.

12. Lee, G., Kwak, Y. H.: An open government maturity model for social media-based public engagement. Government Information Quarterly, 29(4), 492-503 (2012).

13. Linders, D.: From e-government to we-government: Defining a typology for citizen coproduction in the age of social media. Government Information Quarterly, 29(4), 446-454 (2012).

14. Meijer, A.: Government transparency in historical perspective: From the ancient regime to open data in the Netherlands. International Journal of Public Administration, 38(3), 189199 (2015). 
15. Meijer, A. J., Curtin, D., Hillebrandt, M.: Open government: connecting vision and voice. International Review of Administrative Sciences, 78(1), 10-29 (2012).

16. Mergel, I.: Opening government: Designing open innovation processes to collaborate with external problem solvers. Social Science Computer Review, 33(5), 599-612 (2015).

17. Nam, T.: Suggesting frameworks of citizen-sourcing via Government 2.0. Government Information Quarterly, 29(1), 12-20 (2012).

18. Neshkova, M. I., Guo, H.: Public participation and organizational performance: Evidence from state agencies. Journal of Public Administration Research and Theory, 22(2), 267288 (2011).

19. Salge, T. O., Vera, A.: Benefiting from public sector innovation: The moderating role of customer and learning orientation. Public Administration Review 72 (4): 550-60 (2012).

20. Schmidthuber, L., Hilgers, D.: Unleashing Innovation beyond Organizational Boundaries: Exploring Citizensourcing Projects. International Journal of Public Administration, 41(4): 268-283 (2018).

21. Schmidthuber, L., Hilgers, D., Gegenhuber, T., Etzelstorfer, S.: The emergence of local open government: Determinants of citizen participation in online service reporting. Government Information Quarterly, 34(3), 457-469 (2017).

22. Williamson, O.E: Strategy research: governance and competence perspectives. Strategic Management Journal, 29(12), 1087-1108 (1999).

23. Wirtz, B. W., Birkmeyer, S.: Open government: Origin, development, and conceptual perspectives. International Journal of Public Administration, 38(5), 381-396 (2015).

24. Yukl, G.: Leadership in Organizations, 6th edition. Upper Saddle River, NJ: Pearson Prentice Hall (2006).

25. Zhang, F., Feeney, M. K.: Managerial Ambivalence and Electronic Civic Engagement: The Role of Public Manager Beliefs and Perceived Needs. Public Administration Review, 78(1), 58-70 (2018). 